\title{
PEMBENTUKAN PRODUK HUKUM DAERAH SELAMA PANDEMI COVID-19
}

\section{LOCAL LEGAL PRODUCT MAKING DURING COVID-19}

\author{
Victor Juzuf Sedubun ${ }^{1}$ \\ ${ }^{1}$ Dosen HTN/HAN dan Ketua Pusat Kajian HTN Fakultas Hukum, Universitas Pattimura \\ Jl. Ir. M. Putuhena - Kampus Poka, Ambon, Maluku, 97233 \\ Email: sedubunjuzufvictor@gmail.com
}

\begin{abstract}
The Covid-19 pandemic the current issue demands proper and immediate response from the Governments. There are lot of Legal Products that has been made by the government. The public do not solely demand immediate and appropriate response from the central and regional government but also their need to be guaranteed and protected, also the norm in the in the legal product that being made must have the connective power and the efficiency. The practice of formal and substantial principles should be a concern in legal product making in the region, that being formed during the pandemic of Covid-19. Maluku Governor Regulation Number 15/2020 has a lot of material content in common with DKI Jakarta Governor Regulation No. 33/2020.
\end{abstract}

Keywords: Legal Product, Maluku governor regulation Number 15/2020, Covid19.

\section{Intisari}

Langkah cepat dan tepat perlu dilakukan pemerintah dan pemerntah daerah dalam menangani pandemi Covid-19 dengan membentuk produk hukum daerah, baik yang bersifat legislasi maupun yang bersifat regulasi. Kesejahteraan dan keselamatan masyarakat harus terjamin, di samping norma produk hukum yang dihasilkan harus memiliki daya guna dan daya ikat bagi masyarakat. Pergub Maluku Nomor 15 Tahun 2020 yang memiliki banyak kesamaan materi muatan dengan Pergub DKI Jakarta Nomor 33 Tahun 2020, harus dicabut dan diganti dengan pergub yang baru, yang materi muatannya memenuhi prinsip-prinsip pembentukan perundang-indangan yang baik dan mencerminkan konsep Good Covid-19 Governance, agar dapat dilaksanakan dan memberi perlindungan kepada masyarakat.

Kata kunci: Produk hukum, Pergub Maluku Nomor 15/2020, Covid-19

\section{A. Pendahuluan}

Pandemi Corona Virus Diseases 2019 (Covid-19) mulai mewabah di WuhanCina sejak akhir tahun 2019.Penyebaran yang sangat cepat dan meluas mengakibatkan dalam waktu yang singkat pasca pertama kali menyebar di Cina, pandemi Covid-19 telah mewabah 212negara di dunia.Di Indonesia sendiri, pandemi Covid-19 telah mewabah di seluruh provinsi. 
Penyebaran pandemi Covid-19 yang sangat cepat dan meluas ini menuntut Pemerintah untuk mengambil langkah cepat dan tepat dalam penanganannya guna mengatasi dan menekan penyebaran pandemi Covid-19. Penerbitan produk hukum di tingkat pusat, baik dalam bentuk regeling maupun dalam bentukbeschikking, menjadi sangat mendesakdan dinanti oleh setiap daerah, karena produk hukum yang diterbitkan akan menjadi dasar dalam pembentukan produk hukum di tingkat daerah terkait penanganan Pandemi Covid-19.

Pemerintah Daerah sebagai sub ordinat dari Pemerintah juga dituntut mengambil langkah cepat dan tepat untuk menekan angka penyebaran pandemi Covid-19 pada daerah masing-masing. Langkah cepat dan tepat dapat terwujud dalam produk hukum daerah yang dibentuk selama pandemi Covid-19.Langkah cepat Pemerintah dan Pemerintah Daerah dalam menerbitkan produk hukum guna mengatasi dan menekan penyebaran pandemi Covid-19 tidak serta merta dapat menyampingkan substansi dan prosedur pembentukan sebuah produk hukum, sebagaimana diatur dalam peraturan perundangan.

Undang-Undang Nomor 12 Tahun 2011 tentang Pembentukan Peraturan Perundang-undangan (UU Nomor 12 Tahun 2011) sebagaimana telah diubah dengan Undang-undang Nomor 15 Tahun 2019 tentang Perubahan Atas UndangUndang Nomor 12 Tahun 2011 tentang Pembentukan Peraturan Perundangundangan (UU Nomor 15 Tahun 2019) merupakan acuan dalam pembentukan peraturan perundang-undangan di Indonesia, disamping peraturan perundangundangan lain yang memberikan kewenangan kepada badan/pejabat administrasi pemerintahan pada setiap tingkatan untuk membentuk produk hukum berdasarkan kebutuhan dan kepentingan daerah dalam menghadapi Pandemi Covid-19.

Menyikapi pandemi Covid-19, pemerintahan daerahberkewajiban untuk menjaga stabilitas di daerah masing-masing, dengan tetap mengupayakan mengatasi dan menekan penyebaran pandemi Covid-19.Pembentukan produk hukum untukmengatasi dan menekan penyebaran pandemi Covid-19 menjadi langkah hukum yang ditempuh oleh pemerintah daerah.Hal ini sejalan dengan pendapatAndrew Arden ${ }^{1}$ yang menyatakan:

"Local government does not exist in a vacuum. Its purpose is to provide for the peoples of their areas that which is or may not be provided by others, whether the private sector or indeed other organs of government (central and appointed bodies with central or local governmental functions). Accordingly, local government is an essential part of the organisation of the state as a whole and, as such, is both regulated by, and accountable to, central government, with which and with other bodies its functions coexist".

Pembentukan produk hukum daerah dalam kondisi yang tidak seperti saat ini, memang tidak dimungkinkan dalam bentuk peraturan daerah.Dalam membentuk peraturandaerah, membutuhkan adanya persetujuan bersama antara

${ }^{1}$ Andrew Arden, Local Government Constitutional Law and Administrative Law, Thompson Sweet\&Maxwell, London, 2008, hlm. 84. 
Pemerintah Daerah dan Dewan Perwakilan Rakyat Daerah (DPRD) selaku Pemerintahan Daerah yang berwenang secara atributif dalam pembentukan peraturan daerah.

Pembentukan produk hukum daerah dalam kondisi yang tidak normal seperti saat Pandemi Covid-19, tetap harus dilakukan dengan tetap harus memedomani prinsip-prinsip formal dan prinsip-prinsip substansial pembentukan peraturan perundang-undangan yang baik, selain mengacu pada prinsipprinsipformal dan prinsip-prinsip substansial sebagaimana terdapat dalam pengaturan UU Nomor 12 Tahun 2011.

Situasi pandemi Covid-19 saat ini, masyarakat mmembutuhkan langkah cepat dan tepat dari pemerintahan dalam mengatasi dan menekan penyebaran Pandemi Covid-19, tetapi kepastian hukum juga dibutuhkan agar ketertiban masyarakat tetap terjaga.Pembentukan Peraturan Gubernur merupakan langkah cepat dan tepat di masa pandemic Covid-19 dengan tetap memperhatikan asas formal dan asas substansial dalam Pasal 5 dan Pasal 6 UU Nomor 12 Tahun 2011.Selain memerhatikan fungsi peraturan gubernur sebagaimana dikemukakan oleh Maria Farida Indrati Seprapto bahwa "Fungsi peraturan kepala daerah ini merupakan fungsi delegasian dari peraturan daerah, atau dari suatu peraturan perundang-undangan yang lebih tinggi..."2

Perlu juga memerhatikan pendapat Jimly Asshiddiqie bahwa berpijak pada uraian di pendahuluan, masalah yang diangkat untuk dianalisa dalam penulisan ini adalah "bagaimana pembentukan produk hukum di Provinsi Maluku dalam mengatasi dan menekan pandemi Covid-19?"

\section{B. Pembahasan}

1. Kewenangan Pembentukan Produk Hukum Daerah Selama Pandemi Covid-19

Negara Indonesia sebagaimana diamanatkan dalam Pasal 1 ayat (1) Undang-Undang Dasar Negara Republik Indonesia Tahun 1945 (UUD NRI Tahun 1945) adalah negara kesatuan yang berbentuk Republik.Pengaturan bentuk Negara Indonesia menurut Pasal 1 ayat (1) UUD NRI Tahun 1945 adalah sangat penting mengingat letak geografis Negara Indonesia yang terdiri dari banyak pulau. Dengan jangkauan wilayah yang sangat luas.

Negara kesatuan merupakan negara dengan susunan negara yang hanya terdiri atas satu negara saja dan tidak dikenal adanya negara di dalam negara sebagaimana yang dikenal dalam suatu negara federal.Negara kesatuan tidak memiliki wilayah di dalamnya yang berstatus negara, sebagaimana pendapat Ernest Utrecht, yang melihat hubungan dengan negara kesatuan yang tidak terdiri atas beberapa daerah yang berstatus negara bagian. Menurut Ernest Utrecht ${ }^{3}$ : “... suatu negara kesatuan ialah suatu negara yang tidak terdiri dari beberapa daerah yang berstatus negara bagian (deelstaat) dengan undang-undang dasar

${ }^{2}$ Maria Farida Indrati Soeprapto, Ilmu Perundang-undangan, Jenis, Fungsi dan Materi Muatan, Kanisius, Yogyakarta, 2007, hlm. 233.

${ }^{3}$ Ernst Utrecht, Pengantar dalam Hukum Indonesia, Ichtiar Baru bekerja sama dengan Sinar Harapan, Jakarta, 1983, hlm. 342. 
sendiri, biasanya juga dengan kepala negara sendiri dan materi-materi sendirisendiri, serta merdeka dan berdaulat."

Esensi atau hakekat negara kesatuan menurut C. F. Strong ${ }^{4}$, adalah:

"the essence of a unitary state is that the sovereignty is undivided, in other word, that the powers of the central government are unrestricted, for the constitution of a unitary state does not admit of any other law-making body than the central one. If the central power finds it convenient to delegate powers to minor bodies-whether they be local authorities or colonial authorities --- it does so, be it remembered, from the plenitude of its own authority and not because the constitution says it must, or because the various part of the state have a separate indentity which they have some extent retained on joining the larger body. ... that they exist and can be abolished at the discretion of the central authority. ... And, finnaly, it means that there is no possibility of the central and local authorities coming into a conflict with which the central government has not the legal power to cope."

Pendapat C. F. Strong di atas menunjukkan bahwa hakekat suatu negara kesatuan adalah negara yang kedaulatannya tidak terbagi, atau dengan kata lain, negara yang kekuasaan pemerintah pusatnya tidak terbatas karena konstitusi negara kesatuan tidak mengakui adanya badan pembuat undang-undang selain badan pembuat undang-undang pusat.Dengan demikian, dapat dipahami bahwa dalam negara kesatuan, pemerintah pusatlah yang memegang kedaulatan tertinggi negara. Sehingga perlu adanya pengawasan dan pembatasan terhadap penggunaan kedaulatan dalam aktivitas pemerintah pusat dalam undang-undang.

Konsekuensi prinsip negara kesatuan, maka kekuasaan pemerintahan tetap berada di Pemerintah Pusat.Pemerintah selanjutnya melimpahkan wewenang penyelenggaraan pemerintahan di daerah kepada Pemerintahan Daerah.Pelimpahan wewenang kepada Pemerintahan Daerah dalam bentuk desentralisasi.Desentralisasi dalam ketatanegaraan berakibat pada beralihnya kewenangan Pemerintah secara tetap.Pemerintahan kehilangan kewenangan yang telah dilimpahkannya dan beralih kepada Pemerintahan Daerah. Desentralisasi adalah juga cara atau sistem untuk mewujudkan asas demokrasi yang memberikan kesempatan kepada rakyat untuk turut serta berpartisipasi dalam proses penyelenggaraan pemerintahan negara.

M.C. Burkens, et.al ${ }^{5}$, mengemukakan 2 (dua) macam desentralisasi, yaitu desentralisasi teritorial (decentralisatie territorial) dan desentralisasi fungsional (functionale decentralisatie), bahwa:

"Bij territoriale decentralisatie krijgen de organen van een bepaald openbaar licham in beginsel een algemene bevoegdheid tot wetgeving en bestuur op een deel van het grondgebied van de straat, sedangkan

${ }^{4}$ C.F. Strong, Modern Political Constitutions an Introduction to the Comparative Study of their History and Existing Form, Fifth Printed, Sidwick \& Jackson Limited, London, 1960, p. 80.

${ }^{5}$ M.C. Burkens, Beginselen van de Democratische Rechtsstaat, W.E.J. Tjeenk Willenk, Deventer, 1997 , p. 260-263. 
decentralisatie functionale goot het om taakbehartiging met het oog op een bepaald doel".

("Artinya bahwa desentralisasi tidak dimaksudkan sebagai proses melepaskan diri sama sekali dari pemerintah yang lebih atas, tetapi desentralisasi lebih dikaitkan dengan persoalan pembagian/penyerahan wewenang dari lembaga yang lebih tinggi kepada lembaga yang lebih rendah dan yang berada di bawahnya").

Kewenangan penyelenggaraan pemerintahan di daerah oleh Pemerintahan Daerah termasuk di dalamnya kewenangan untuk menetapkan peraturan daerah dan peraturan-peraturan lain sebagai dasar melaksanakan otonomi dan tugas pembantuan. Atribusi ini termaktub dalam ketentuan Pasal 18 ayat (5) dan ayat (6) UUD NRI Tahun 1945 yang menyatakan:

(5) Pemerintahan daerah menjalankan otonomi seluas-luasnya, kecuali urusan pemerintahan yang oleh undang-undang ditentukan sebagai urusan Pemerintah Pusat.

(6) Pemerintahan daerah berhak menetapkan peraturan daerah dan peraturan-peraturan lain untuk melaksanakan otonomi dan tugas pembantuan.

Ketentuan Pasal 18 ayat (5) dan ayat (6) UUD NRI Tahun 1945 merupakan dasar konstitusionalitas kewenangan Pemerintahan Daerah membentuk peraturan daerah dan peraturan-peraturan lain dalam rangkan penyelenggaraan pemerintahan di daerah berdasarkan otonomi dan tugas pembantuan.Otonomi ditidak dapat dimaknai sebagai kemerdekaan. MenurutLaica Marzuki ${ }^{6}$ :

"Otonomi daerah merupakan esensi pemerintahan desentralisasi.Istilah
otonomi berasal penggalan dua kata bahasa Yunani, autos yang berarti
sendiri dan nomos yang berarti undang-undang.Otonomi bermakna
membuat perundang-undangan sendiri (zelfwetgeving), namun dalam
perkembangannya, konsepsi otonomi daerah selain mengandung arti
zelfwetgeving (membuat Peraturan Daerah-Peraturan Daerah), juga
utamanya mencakup zelfbestuur (pemerintahan sendiri). C.W. van der Pot
memahami konsep otonomi daerah sebagai eigen huishouding
(menjalankan rumah tangganya sendiri)."

Kebebasan yang ada tidak serta merta merupakan kebebasan yang tanpa memikirkan anggota masyarakat. Ibaratnya suatu rumah tangga keluarga, maka dalam menjalankan tugas dan fungsi sebagai kepala keluarga, kepala keluarga harus memperhatikan kenyamanan, kebutuhan dan pendapat anggota keluarga yang lain. Harus ada batasan-batasan dalam pergaulan dalam keluarga. Di samping itu juga harus ada batasan-batasan yang mengatur pergaulan antara keluarga yang satu dengan keluarga yang lain. Sehingga tercipta keberaturan dan ketertiban hidup, bukan saja dalam keluarga namun juga dengan tetangga dalam

${ }^{6}$ M. Laica Marzuki, Berjalan-Jalan di Ranah Hukum, Buku Kesatu, Edisi Revisi Cetakan Kedua, Sekretariat Jenderal dan Kepaniteraan Mahkamah Konstitusi RI, Jakarta, 2006, hlm. 161.

Suloh Jurnal Program Studi Magister Hukum, Edisi Khusus, Oktober 2020, pp. 5 - 20 
lingkungannya.Konsep otonomi nyata dan bertanggungjawab bertujuan untuk meningkatkan pelayanan kepada masyarakat.

Selanjutnya Philipus M. Hadjon ${ }^{7}$ mengatakan bahwa:

"Menjadikan kerukunan sebagai saringan terhadap ekspansi birokrasi dapatlah dibandingkan dengan usaha yang telah dikembangkan dalam Hukum Administrasi di Belanda melalui apa yang disebut 'algemene beginselen van behoorlijk bestuur'. Asas ini beranjak dari pemikiran bahwa penguasa dalam segala tingkah-lakunya hendaklah bertindak sebagai halnya seorang bapak rumah tangga yang baik (als een goed huisvader). Asas ini di Belanda dimaksudkan sebagai sarana pengawasan terhadap kebebasan bertindak dari penguasa (berdasarkan asas 'freis ermessen')"

Abdurrahman Wahid menyatakan bahwa Indonesia adalah rumah besar yang di dalamnya penuh warna. ${ }^{8}$ Penulis mengartikan pendapat sebagai Indonesia sebagai suatu tubuh yang memiliki banyak anggota.Jika dihubungkan dengan ilustrasi di atas, maka dapat dikatakan bahwa masing-masing anak memiliki karakter dan potensi tersendiri yang harus diberikan keleluasaan untuk dikembangkan.Sehingga orang tua tidak dapat memaksa karakter dan potensi orang tua menjadi karakter dan potensi anak.Orang tua selanjutnya hanya mengawasi dan memberikan pengarahan kepada anak, agar anak tidak berlaku meyimpang dari nasihat orang tua.Dalam hubungan antar anggota keluarga, maka satu anggota tidak dapat menganggap dirinya lebih penting dari anggota yang lain. Dengan begitu, sangat diperlukan adanya kerukunan dalam hubungan orang tua dan anak.

Penetapan produk hukum daerah, dalam konteks negara kesatuan seperti iluistrasi di atas, dapat disampaikan bahwa penetapan peraturan daerah maupun peraturan-peraturan lainnya oleh Pemerintahan Daerah tetap mengacu pada hierarki peraturan perundang-undangan yang berlaku di Indonesia, sebagaimana diatur dalam ketentuan UU Nomor 12 Tahun 2011.Pengaturan jenis dan hierarki perturan perundang-undangan dalam UU Nomor 12 Tahun 2011 terdapat dalam ketentuan Pasal ayat (1) dan Pasal 8 ayat (1) yang menyatakan sebagai berikut:

Pasal 7 ayat (1) Jenis dan hierarki Peraturan Perundang-undangan terdiri atas:

a. Undang-Undang Dasar Negara Republik Indonesia Tahun 1945;

b. Ketetapan Majelis Permusyawaratan Rakyat;

c. Undang-Undang/Peraturan Pemerintah Pengganti Undang-Undang;

d. Peraturan Pemerintah;

e. Peraturan Presiden;

f. Peraturan Daerah Provinsi; dan

${ }^{7}$ Philipus M. Hadjon, Perlindungan Hukum Bagi Rakyat di Indonesia, Sebuah Studi tentang Prinsip-Prinsipnya, Penangannya oleh Pengadilan dalam Lingkungan Peradilan Umum dan Pembentukan Peradilan Administrasi, Peradaban, Surabaya, 2007, hlm. 89.

${ }^{8}$ Sebagaimana dikemukakan oleh Mahfud MD, dalam wawancara dengan Metro TV pada acara Nasib Capres Partai Tengah, Kamis, 10 April 2014, Pukul 08.30 WIB. 
g. Peraturan Daerah Kabupaten/Kota.

Pasal 8 ayat (1) Jenis Peraturan Perundang-undangan selain sebagaimana dimaksud dalam Pasal 7 ayat (1) mencakup peraturan yang ditetapkan oleh Majelis Permusyawaratan Rakyat, Dewan Perwakilan Rakyat, Dewan Perwakilan Daerah, Mahkamah Agung, Mahkamah Konstitusi, Badan Pemeriksa Keuangan, Komisi Yudisial, Bank Indonesia, Menteri, badan, lembaga, atau komisi yang setingkat yang dibentuk dengan Undang-Undang atau Pemerintah atas perintah Undang-Undang, Dewan Perwakilan Rakyat Daerah Provinsi, Gubernur, Dewan Perwakilan Rakyat Daerah Kabupaten/Kota, Bupati/Walikota, Kepala Desa atau yang setingkat.

Pemerintahan Daerah berwenang untuk membentuk produk hukum daerah yang bersifat regeling di tingkat provinsi meliputi peraturan daerah provinsi, peraturan gubernur, dan peraturan DPRD provinsi.Sedangkan produk hukum daerah yang bersifat regeling di tingkat kabupaten/kota meliputi peraturan daerahkabupaten/kota dan peraturan bupati/walikota, dan peraturan DPRD kabupaten/kota.Selain itu terdapat pula produk hukum daerah yang bersifat beschikking berupa keputusan-keputusan yang dikeluarkan oleh kepala daerah.

Daerah otonom menurut Bagir Manan ${ }^{9}$, sebagai satu pemerintahan mandiri yang memiliki wewenang atributif - lebih-lebih sebagai subyek hukum (publiek rechtpersoon, public legal entity) - berwenang membuat peraturan-peraturan untuk menyelenggarakan rumah tangganya. Wewenang mengatur ini ada pada Pemerintah Daerah (pejabat administrasi negara) dan DPRD sebagai pemegang fungsi legislatif di daerah.

Pembentukan produk hukum daerah harus sesuai kewenangan yang diberikan, sebagaimana juga diatur dalam ketentuan Pasal 8 ayat (2) UU Nomor 2 Tahun 2011 menyatakan bahwa: peraturan Perundang-undangan sebagaimana dimaksud pada ayat (1) diakui keberadaannya dan mempunyai kekuatan hukum mengikat sepanjang diperintahkan oleh Peraturan Perundang-undangan yang lebih tinggi atau dibentuk berdasarkan kewenangan.

Hakekat peraturan daerah dan peraturan-peraturan lainnya sebagai produk hukum daerah yang mengakomodir kepentingan masyarakat di daerah guna mencapai suatu kebahagiaan yang terbesar kepada masyarakat, mesti dihargai oleh penyelenggara pemerintahan di pusat sebagai urusan penyeleggara pemerintahan di daerah dalam mengupayakan kebahagiaan dan kesejahteraan kepada masyarakat di daerah.Dengan pengakuan tersebut, daerah berhak menetapkan produk hukum daerah untuk menampung kondisi khusus daerah dan mengatur kehidupan bersama masyarakat di daerahnya dalam pergaulan antar individu. Pemerintah di pusat tidak lagi dapat mengintervensi pembentukan produk hukum daerah, sekalipun muatan materi produk hukum daerah yang dibentuk oleh penyelenggara pemerintahan di daerah terdapat pertentangan dengan peraturan yang lebih tinggi, kecuali jika mutan materi tersebut bertentangan dengan konstitusi, undang-undang dan tujuan pembentukan produk hukum daerah itu sendiri.Pendapat Andrew Arden dapat menjadi acuan

${ }^{9}$ Bagir Manan,Teori dan Politik Konstitusi, FH UII Press, Yogyakarta,2003, hlm. 71. 
sebagaimana dikemukakan di atas dapat menjadi acuan, bahwa pemerintah daedrah tidak dapat tinggaldiam dan tidak melakukan apa. ${ }^{10}$

Pemerintah Daerah menyediakanbagi rakyatdaerahnya sesuai dengan kebutuhan dan kondisi khusus di daerah, sepanjang masih dapat dipertanggungjawabkan oleh Pemerintah Daerah.Dalam kaitan dengan pembentukan peraturandaerah, maka pemerintahan daerah yang paling tahu mengapa, untuk siapa, kapan dan bagaimana aturan tersebut dibuat ${ }^{11}$ dan dampaknya terhadap perkembangan masyarakat di daerah.

\section{Prinsip Pembentukan Produk Hukum Daerah}

Pembentukan suatu produk hukum, termasuk produk hukum daerah, memerlukan adanya suatu keahlian dan keterampilan.Suatu produk hukum daerah harus dapat memberikan jaminan perlindungan dan pemenuhan kepentingan bersama masyarakat di daerah.Lon Fuller, memberikan pendapat bahwa membentuk aturan hukum, termasuk membentuk undang-undang dan Peraturan Daerah dan peraturan-peraturan lainnya (cetak miring oleh penulis) itu adalah suatu keterampilan. ${ }^{12}$

Pembentukan peraturan perundang-undangan menururt Lon Fuller, ${ }^{13}$ seharusnya dilakukan sesuai kewenangan yang dimiliki serta cermat, hal ini untuk menghindari kegagalan penerapan peraturan perundang-undangan yang dibentuk karena adanya pembatalan atau karena materi muatannya sangat sulit untuk dipenuhi oleh masyarakat.Peraturan yang baik bagi masyarakat harus mencakup delapan hal (eight ways to fail to make law), sebagai berikut:

"eight ways to fail to make law is:

(a) ... a failure to achieve rules at all, so that every issue must decided on an ad hoc basic (peraturan harus juga berlaku bagi penguasa, harus ada kecocokan atau konsistensi antara peraturan yang diundangkan dengan pelaksanaannya; dituangkan dalam aturan-aturan yang berlaku umum, artinya suatu sistem hukum harus mengandung peraturan-peraturan dan tidak boleh sekedar mengandung keputusan-keputusan yang bersifat sementara atau ad hoc);

(b) a failure to publicize, or at least to make avaiable to the affected party, the rules he is expacted to observe (aturan-aturan yang telah dibuat harus diumumkan kepada mereka yang menjadi obyek pengaturan aturan-aturan tersebut);

(c) the abuse of retroactive legislation, which not only cannot itself guide action, but undercuts the integrity of rules prospective in effect, since it

\footnotetext{
${ }^{10}$ Andrew Arden, Loc.Cit.

${ }^{11}$ Jimly Asshiddiqie, Hukum Tata Negara dan Pilar-Pilar Demokrasi, Serpihan Pemikiran Hukum, Media dan HAM, Konstitusi Press, Jakarta, 2005, hlm. 67.

${ }^{12}$ I Made Subawa,"Implikasi Yuridis Pengalihan Kekuasaan Membentuk Undang-Undang Terhadap Sistem Ketatanegaraan Republik Indonesia Pasca Perubahan Undang-Undang Dasar 1945”, Disertasi, PPS Unair, Surabaya, 2003, h. 10.

${ }^{13}$ Sebagaimana dikutip oleh Taufiqurrohman Syahuri, "Hukum Konstitusi (Proses dan Prosedur Perubahan UUD 1945 di Indonesia 1945-2002)", Ghalia Indonesia, Jakarta, 2004, h. 2122.
} 
uts them under the threat of retrospective change (tidak boleh ada peraturan yang memiliki daya laku surut atau harus non-retroaktif, karena dapat merusak integritas peraturan yang ditujukan untuk berlaku bagi waktu yang akan datang);

(d) a failure to make rules understandable (dirumuskan secara jelas, artinya disusun dalam rumusan yang dapat dimengerti);

(e) the enactment of contradictory rules (tidak boleh mengandung aturanaturan yang bertentangan satu sama lain);

(f) that rules require conduct beyond the powers of the affected party (tidak boleh mengandung beban atau persyaratan yang melebihi apa yang dapat dilakukan);

(g) intoduction such frequent changes in the rules that the subject cannot orient his action by them (tidak boleh terus-menerus diubah, artinya tidak boleh ada kebiasaan untuk sering mengubah-ubah peraturan sehingga menyebabkan seseorang kehilangan orientasi); dan

(h) a failure of congruence between the rules as announced and their actual administration (harus ada kecocokan atau konsistensi antara peraturan yang diundangkan dengan pelaksanaan sehari-hari)".

Pembentukan hukum tersebut harus didasarkan pada kebenaran fakta yang terjadi dalam masyarakat.Berdasarkan kebenaran fakta tersebut pembentukan hukum harus dapat memenuhi kebutuhan masyarakat terhadap suatu aturan tertentu yang mengendalikan perilaku individu dalam masyarakat.Geofferey Samuel ${ }^{14}$ mengemukakan bahwa:

"The object of legal science is the constructed legal model of facts. The idea that the way facts are constructed internally leading to the way that they are thus viewed, is capable of creating a normative dimension quite separate from any normative aspect attaching to a legal rule. This fact construction can be seen as a kind of precategorisation before the facts are formally assigned to an established legal category. How facts are actually constructed at this precategorisation stage might well be an active step in the process of reaching a solution in a case and thus the construction - and reconstruction - of facts is as important as any search for, or an application of, a rule. The facts of a case are not real facts. They are not real-life situations, but are virtual fact because the object of legal science is not the phenomena of the real world (real facts of a case)."

Peran lembaga-lembaga hukum dan konsep merupakan pusat penyelidikan yang dilakukan secara epistemologis dan metodologis hukum.Peran lembagalembaga hukum dan konsep juga sebagai jembatan untuk menghubungkan antara dunia hukum dan fakta sosial. Ada tiga instansi fundamental: orang (persona), hal

${ }^{14}$ Geofferey Samuel, Epistimology and Method in Law, Kent Law School, UK, Juridishe Bibliotheek University Utrecht, 2007, p. 175. 
(res), dan tindakan (actio). Peraturan daerah dan peraturan kepala daerah sebagai produk hukum lokal, memiliki peran yang sama dengan pandangan di atas, yaitu sebagai jembatan penghubungan antara antara dunia hukum dan fakta sosial. Apa yang menjadi cita hukum dalam produk hukum daerah harus dapat dihubungkan dengan kepentingan dari masyarakat di daerah.

Prinsip-prinsip hukum mempunyai arti penting bagi pembentukan hukum, penerapan hukum dan pengembangan ilmu hukum, karena bagi pembentukan hukum, prinsip-prinsip hukum memberikan landasan secara garis besar mengenai ketentuan-ketentuan yang perlu dituangkan ke dalam aturan hukum. ${ }^{15}$

Van der Vlies dalam buku Het Wetsbegrijp en Beginselen van Behoorlijke Regeling,membagi prinsip-prinsip dalam pembentukan peraturan-peraturan yang patut (beginselen van behoorlijke regelgeving) ke dalam asas-asas formal dan prinsip-prinsip yang material. Prinsip-prinsip yang formal dibagi atas lima, yaitu: prinsip tujuan yang jelas (beginsel van duideleijke doelstelling); prinsip organ/lembaga yang jelas (beginsel van het juiste orgaan); prinsip perlunya pengaturan (het noodzakelijkheidsbeginsel); prinsip dapat dilaksanakan (het beginsel van uitvoerbaarheid); dan prinsip konsensus (het beginsel van consensus). ${ }^{16}$

Sedangkan mengenai prinsip-prinsip yang material, van der Vlies membagi atas lima, yaitu prinsip terminologi dan sistematika yang benar (het beginsel van duidelijke terminologie en duidelijke systematiek); prinsip dapat dikenali (het beginsel van de kenbaarheid); prinsip perlakuan yang sama dalam hukum (het rechtsgelijkheidsbeginsel); prinsip kepastian hukum (het rechtszekerheidsbeginsel); dan prinsip pelaksanaan hukum sesuai dengan keadaan individual (het beginsel van individuele rechtsbedeling). ${ }^{17}$

Selanjutnya, A. Hamid S. Attamimi cenderung untuk membagi prinsipprinsip pembentukan peraturan perundang-undangan yang patut tersebut ke dalam:

a. Prinsip-prinsip formal, dengan perincian:

1) prinsip tujuan yang jelas;

2) prinsip perlunya pengaturan;

3) prinsip organ/lembaga yang tepat;

4) prinsip materi muatan yang tepat;

5) prinsip dapatnya dilaksanakan; dan

6) prinsip dapatnya dikenali.

b. Prinsip-prinsip material, dengan perincian:

1) prinsip sesuai dengan Cita Hukum Indonesia dan Norma Fundamental Negara;

2) prinsip sesuai dengan Hukum Dasar Negara;

3) prinsip sesuai dengan prinsip-prinsip Negara Berdasar Atas Hukum;

\footnotetext{
${ }^{15}$ Dikembangkan dari pendaapat J.H.P. Bellefroid. "Inleiding tot de Rechtswetenschap in Nederland". Dekker \& van de Vegt. Nijmegen. 1953. Dalam Peter Mahmud Marzuki. Penelitian Hukum. Kencana. Jakarta. 2010. hlm. 79.

${ }^{16}$ Maria Farida Indrati Soeprapto. Ilmu Perundang-Undangan, Dasar-Dasar dan Pembentukannya. Cetakan Kesebelas. Kanisius. Yogyakarta. 2006. hlm. 196.

${ }^{17}$ Ibid., hlm. 197.
} 
4) prinsip sesuai dengan prinsip-prinsip Pemerintahan Berdasarkan Sistem Konstitusi. $^{18}$

Mengacu pada prinsip-prinsip pembentukan peraturan perundang-undangan Indonesia yang patut tersebut, dapat diharapkan terciptanya peraturan perundangundangan yang baik dan dapat mencapai tujuan secara optimal dalam pembangunan hukum di Indonesia.Berkaitan dengan prinsip-prinsip pembentukan peraturan perundang-undangan dalam peraturan perundang-undangan di Indonesia, maka penulis akan membahas prinsip-prinsip pembentukan perundangundangan yang diatur dalam UU Nomor 10 Tahun 2004 sebagaimana telah diganti dengan Undang-Undang Nomor 12 Tahun 2011 beserta perubahannya.

Pasal 5 UU Nomor 12 Tahun 2011 memuat beberapa prinsip-prinsip yang harus menjadi acuan dalam pembentukan peraturan perundang-undangan.Prinsipprinsip tersebut beserta penjelasannya adalah sebagai berikut:

a. kejelasan tujuan, yaitu bahwa bahwa setiap pembentukan peraturan perundang-undangan harus mempunyai tujuan yang jelas yang hendak dicapai;

b. kelembagaan atau organ pembentuk yang tepat, yaitu bahwa setiap jenis peraturan perundang-undangan harus dibuat oleh lembaga negara atau pejabat pembentuk peraturan perundang-undangan yang berwenang. peraturan perundang-undangan tersebut dapat dibatalkan atau batal demi hukum apabila dibuat oleh lembaga negara atau pejabat yang tidak berwenang;

c. kesesuaian antara jenis dan materi muatan, yaitu bahwa dalam pembentukan peraturan perundang-undangan harus benar-benar memperhatikan materi muatan yang tepat sesuai dengan jenis dan hierarki peraturan perundangundangan;

d. dapat dilaksanakan, yaitu bahwa setiap pembentukan peraturan perundangundangan harus memperhitungkan efektivitas peraturan perundang-undangan tersebut di dalam masyarakat, baik secara filosofis, sosiologis, maupun yuridis;

e. kedayagunaan dan kehasilgunaan, yaitu bahwa setiap peraturan perundangundangan dibuat karena memang benar-benar dibutuhkan dan bermanfaat dalam mengatur kehidupan bermasyarakat, berbangsa, dan bernegara;

f. kejelasan rumusan, yaitu bahwa bahwa setiap peraturan perundang-undangan harus memenuhi persyaratan teknis penyusunan peraturan perundangundangan, sistematika, pilihan kata atau istilah, serta bahasa hukum yang jelas dan mudah dimengerti sehingga tidak menimbulkan berbagai macam interpretasi dalam pelaksanaannya; dan

g. keterbukaan, yaitu bahwa dalam pembentukan peraturan perundang-undangan mulai dari perencanaan, penyusunan, pembahasan, pengesahan atau penetapan, dan pengundangan bersifat transparan dan terbuka. Dengan demikian, seluruh lapisan masyarakat mempunyai kesempatan yang seluas-

${ }^{18}$ A. Hamid S. Attamimi. "Peranan Keputusan Presiden Republik Indonesia dalam Penyelenggaraan Pemerintahan Negara (Suatu Studi analisis Mengenai Keputusan Presiden yang Berfungsi Pengaturan dalam Kurun Waktu PELITA I-PELITA IV)". Disertasi. Universitas Indonesia. Jakarta. 1990. hlm. 344-345. 
luasnya untuk memberikan masukan dalam pembentukan peraturan perundang-undangan.

\section{Produk Hukum Daerah Maluku Selama Pandemi Covid-19}

Menghadapi pandemi Covid-19, Pemerintah Daerah Provinsi Maluku juga berupaya untuk mengatasi dan menekan penyebaran pandemi Covid-19 melalui berbagai upaya, termasuk mengeluarkan produk hukum daerah. Produk hukum daerah yang dikeluarkan antara lain Peraturan Gubernur Maluku Nomor 15 Tahun 2020 tentangPembatasan Pergerakan Orang dan Moda Transportasi Dalam Penanganan Corona Virus Disease 2019 (Covid-19) di Pulau Ambon (Pergub Maluku Nomor 15 Tahun 2020) yang diundangkan dalam Berita Daerah Provinsi Maluku Tahun 2020 Nomor 47.

Sebelumnya Pemerintah Provinsi Maluku dalam rangka upaya mengatasi dan menekan angka penyebaranpandemi Covid-19 di Provinsi Maluku, telah mengeluarkan kebijakan pemberlakuan Pembatasan Sosial Berskala Regional (PSBR) yang bertujuan membatasi pembatasan pergerakan orang dalam rangka mengatasi dan menekan penyebaran pandemi Covid-19.Ini berarti bahwa dalam upaya mengatasi dan menekan penyebaran pandemi Covid-19 di Maluku, Pemerintah Provinsi Maluku setidaknya telah menetapkan dua langkah besar, yaitu kebijakan pemberlakuan PSBR dan Pergub Maluku Nomor 15 Tahun 2020.

Kedua langkah yang diambil ini dari aspek hukum,khususnya ilmu perundang-undangan akanmenimbulkan permasalahan hukum bagi masyarakat dalam penerapannya. Berikut ini akan dikaji kedua langkah kebijakan yang diambil oleh Pemerintah Provinsi Maluku.

\section{a. Kebijakan Penerapan Pembatasan Sosial Berskala Regional}

Langkah hukum yang pertama dikeluarkan dan menjadi pembahasan dalam penulisan ini adalah Kebijakan tentang Penerapan Pembatasan Social Berskala Regional di Provinsi Maluku yang diumumkan langsung oleh Gubernur Maluku.Dari aspek terminologi, PSBR merupakan terminologi baru dan yang tidak terdapat dalam pengaturan pada peraturan perundang-undangan sebelumnya. Dalam Undang-Undang 6 Tahun 2018 tentang Karantina Kesehatan (UU Nomor 6 Tahun 20018), hanya mengenal karantina wilayah, karantina rumah, karantina rumah sakit dan Pembatasan Sosial Berskala Besar (PSBB).

Pemberlakuan PSBR di Provinsi Maluku hendaknya tidak dikuti dengan adanya sanksi bagi yang melanggarnya.Penerapan PSBR dengan pemberlakuan sanksi bagi yang melanggar akan mengakibatkan permasalahan hukum baru bagi masyarakat dalam penerapannya. Kebijakan Kepala Daerah yang mengandung sanksi tetapi tidak dituangkan dalam suatu bentuk produk hukum daerah, tentu memiliki dampak hukum.Secara administratif pemerintahan,kebijakan Gubernur Maluku dapat dikategorikan sebagai tindakan pejabat administrasi sehingga dapat dijadikan sebagai obyek gugatan pada peradilan tata usaha negara.

Prinsip material pembentukan peraturan perundang-undangan yang dikemukakan oleh van der Vlies, yaitu prinsip terminologi dan sistematika yang jelas, yang menjelaskan bahwa suatu peraturan harus jelas, baik kata-kata yang digunakan maupun strukturnya. Kekuatiran akan kemungkinan penerobosan 
peraturan melalui celah-celah yang ada sering menyebabkan digunakannya susunan kalimat yang amat rumit yang, menurut pembuatnya, mampu mencakup segala kemungkinan yang akan terjadi. Suatu peraturan tidak hanya harus jelas kalimat demi kalimat, tetapi sistematikanya pun harus jelas dan logis. Pembaca mengharapkan adanya argumentasi yang tersusun baik di dalam suatu undangundang dan akan membaca undang-undang dengan cara itu.

Pengambil kebijakan harus menggunakan terminologi yang jelas untuk menggambarkan latar belakang Pemerintah mengambil langkah mengeluarkan kebijakan PSBR.Ketiadaan konsep hukum dan konsep sosial terhadap terminologi PSBR dalam peraturan perundang-undangan yang mendasari dikeluarkan kebijakan PSBR berdampak pada kebijakan yang diambil tidak memiliki dasar hukum yang kuat.

Selain itu mengenai prinsip formal yaitu prinsip tujuan yang jelas juga tidak diacu dalam kebijakan ini.Menurut van der Vlies, ${ }^{19}$ prinsip tujuan yang jelas terdiri atas tiga tingkat, yaitu:

a. kerangka kebijakan umum bagi peraturan yang akan dibuat;

b. tujuan tertentu dari peraturan yang akan dibuat; dan

c. tujuan dari pelbagai bagian dalam peraturan.

Untuk dapat menyatakan dengan jelas tujuan yang ingin dicapai, pembuat kebijakan harus pertama-tama perlu memberikan uraian yang cukup mengenai keadaan-keadaan nyata yang ingin diatasi oleh kebijakan yang ditempuh.Uraian yang dimaksud adalah uraian mengenai keadaan yang senyatanya dari Prvinsi Maluku, akibat pandemi Covid-19, dan langkah yang akan ditempuh melalui kebijakan yang dikeluarkan. Tahap selanjutnya, adalah perlu mengemukakan perubahan-perubahan apa yang melalui peraturan itu dikehendaki terjadi atas situasi nyata yang ada serta harus diuraikan bagaimana ketentuan-ketentuan dalam peraturan itu akan menimbulkan perubahan-perubahan tersebut, dalam uraian itu perlu dimuat ikhtisar mengenai kebaikan dan keburukan dari penerapan kebijakan PSBR dalam rangkan mengatasi dan menekan penyebaran pandemi Covid-19 di Provinsi Maluku.

Kebijakan Pemerintah Daerah (dalam hal ini termasuk Pemerintah Provinsi Maluku) dalam mengeluarkan PSBR dapat dilihat dari aspek administrasi pemerintahan menurut Undang-Undang Nomor 30 Tahun 2014 tentang Administrasi Pemerintahan (UU Nomor 30 Tahun 2014), dapat mengenal tindakan administrasi pemerintahan di samping keputusan administrasi pemerintahan. Pasal 1 angka 8 UU Nomor 30 Tahun 2014 menyatakan bahwa:

Tindakan Administrasi Pemerintahan yang selanjutnya disebut Tindakan adalah perbuatan Pejabat Pemerintahan atau penyelenggara negara lainnya untuk melakukan dan/atau tidak melakukan perbuatan konkret dalam rangka penyelenggaraan pemerintahan.

Tindakan mengeluarkan kebijakan PSBR dalam kaitan dengan administrasi pemerintahan dalam UU Nomor 30 Tahun 2014 dapat dikategorikan sebagai

${ }^{19}$ I.C. van der Vlies. Het Wetsbegrijp en Beginselen van Behoorlijke Regeling. 'sGravenhage. Vuga. 1984. hlm. 186. Seperti dikutip oleh Ibid. hlm. 196-197. 
tindakan administrasi pemerintahan. Pengaturan lebih lanjut terdapat dalam Pasal 9 UU Nomor 30 Tahun 2014 yang menyatakan:

(1) Setiap Keputusan dan/atau Tindakanwajib berdasarkan ketentuanperaturan perundang-undangan dan AUPB

(2) Peraturan perundang-undangan sebagaimana dimaksud pada ayat (1) meliputi:

a. peraturan perundang-undangan yang menjadi dasar Kewenangan; dan

b. peraturan perundang-undangan yang menjadi dasar dalam menetapkan dan/atau melakukanKeputusan dan/atau Tindakan.

(3) Badan dan/atau Pejabat Pemerintahandalam menetapkan dan/atau melakukan Keputusan dan/atau Tindakanwajib mencantumkan atau menunjukkan ketentuanperaturan perundang-undangan yang menjadi dasar Kewenangan dan dasar dalam menetapkan dan/atau melakukanKeputusan dan/atau Tindakan.

(4) Ketiadaan atau ketidakjelasan peraturan perundang-undangan sebagaimana dimaksud pada ayat (2) huruf b, tidak menghalangi Badan dan/atau Pejabat Pemerintahanyang berwenang untuk menetapkan dan/atau melakukan Keputusan dan/atau Tindakansepanjang memberikan kemanfaatan umum dan sesuai dengan AUPB.

Tindakan mengeluarkan kebijakan PSBR tidak dapat menunjukan dasar hukumnya, peraturan perundang-undangan yang menjadi cantolan dikeluarkannya Kebijakan PSBR.Hal ini dikarenakan terminologi PSBR tidak terdapat dalam satupun peraturan perundang-undangan yang menjadi dasar pemberlakuan situasi tidak normal, khususnya dalam situasi Pandemi Covid-19.

Penjelasan umum UU Nomor 30 Tahun 2014 menyatakan bahwa pengaturan administrasi pemerintahan diperlukan dalam rangka memberikan jaminan kepada Warga Masyarakat yang semula sebagai obyek menjadi subyek dalam sebuah negara hukum yang merupakan bagian dari perwujudan kedaulatan rakyat. Kedaulatan Warga Masyarakat dalam sebuah negara tidak dengan sendirinya - baik secara keseluruhan maupun sebagian — dapat terwujud.

Pengaturan administrasi pemerintahan dalam UU Nomor 30 Tahun 2014 memberikan jaminan bahwa keputusan yang dikeluarkan oleh badan dan/atau pejabat administrasi dan/atau tindakan yang dilakukan oleh badan dan/atau pejabat pemerintahan terhadap masyarakat tidak dapat dilakukan dengan semenamena, sehingga menciptakan keadilan dan kepastian hokum dalam masyarakat.

Gubernur Provinsi Maluku selaku pejabat administrasi pemerintahan yang mengeluarkan kebijakan PSBR harus dapat menunjukkan dasar hukum pemberlakuan PSBR. Hal ini untuk menghindari tindakan semena-mena pemerintah terhadap warga masyarakat dalam situasi pandemi Covid-19 saat ini.

\section{b. Peraturan Gubernur Maluku Nomor 15 Tahun 2020}

Pergub Maluku Nomor 15 Tahun 2020 diterbitkan untuk mempertegas dan memberikan dasar hukum yang jelas bagi kebijakan PSBR yang telah dilaksanakan sebelumnya. Pergub Maluku Nomor 15 Tahun 2020 yang ditandatangani oleh Kepala Biro Hukum dan HAM Sekretariat Daerah Provinsi Maluku, dan efektif berlaku sejak tanggal 21 April 2020, dalam draft Pergub 
Maluku yang telah telah tersebar luas di masyarakat terdapat beberapa pengaturan yang menyimpang dari prinsip pembentukan peraturan perundang-undangan.

Materi muatan Pergub Maluku Nomor 15 Tahun 2020 jika dibandingkan dengan judul menjadi tidak sinkron.Dalam teori perundang-undangan, judul peraturan perundang-undangan harus menggambarkan dengan jelas mengenai materi muatan yang diatur dalam peraturan perundang-undangan yang diatur.Ketidaksikronan ini disebabkan karena judul Pergub Nomor 15 Tahun 2020 adalah Pembatasan Pergerakan Orang dan Moda Transportasi dalam Penanganan Corona Virus Disease 2019 (Covid-19) di Pulau Ambon, sedangkan materi muatannya tidakhanya mengatur pembatasan pergerakan orang dan moda transpotasi, namun juga meliputi pengaturan mengenai:

a. penghentian sementara proses belajar mengajar di sekolah dan/atau institusi pendidikan lainnya;

b. pembatasan proses bekerja di tempat kerja;

c. pembatasan kegiatan keagamaan;

d. pembatasan kegiatan di tempat atau fasilitas umum, dan

e. pembatasankegiatan sosial dan budaya.

Pembatasan-pembatasan sebagaimana diatur dalam materi muatan Pergub Maluku Nomor 15 Tahun 2020, memiliki kesamaan dengan materi muatan Pembatasan Sosial Berskala Besar yang telah mendapat persetujuan untuk diberlakukan di daerah lain. Kesamaantersebut dapat diamati dengan membandingkan dengan Peraturan Gubernur Daerah Khusus Ibukota Jakarta Nomor 33 Tahun 2020 tentang Pelaksanaan Pembatasan Sosial Berskala Besar dalam Penanganan Corona Virus Disease 2019 (Covid-19) di Provinsi Daerah Khusus Ibukota Jakarta (Pergub DKI Jakarta Nomor 33 Tahun 2020) yang ditandatangani oleh Kepala Biro Hukum dan HAM Sekretariat Daerah Provinsi DKI Jakarta dan efektif berlaku tanggal 9 April 2020, dapat dibandingkan dalam tabel 1 berikut ini:

Tabel 1

Perbandingan Materi Muatan Pergub Maluku Nomor 15 Tahun 2020 dengan Pergub DKI Jakarta Nomor 33 Tahun 2020

\begin{tabular}{|c|c|c|}
\hline & $\begin{array}{lll}\text { Pergub Maluku } & \text { Nomor } & 15 \\
\text { Tahun 2020 } & & \\
\end{array}$ & $\begin{array}{l}\text { Pergub DKI Jakarta Nomor } 33 \\
\text { Tahun } 2020\end{array}$ \\
\hline Judul & $\begin{array}{l}\text { Pembatasan Pergerakan Orang dan } \\
\text { Moda Transportasi dalam } \\
\text { Penanganan Corona Virus Disease } \\
2019 \text { (Covid-19) di Pulau Ambon }\end{array}$ & $\begin{array}{l}\text { Pelaksanaan Pembatasan Sosial } \\
\text { Berskala Besar dalam Penanganan } \\
\text { Corona Virus Disease } 2019 \text { (Covid- } \\
\text { 19) di Provinsi Daerah Khusus } \\
\text { Ibukota Jakarta }\end{array}$ \\
\hline $\begin{array}{l}\text { Dasar } \\
\text { Hukum }\end{array}$ & $\begin{array}{l}\text { 1. Undang-Undang Nomor } 4 \text { Tahun } \\
1984 \text { tentang Wabah Penyakit } \\
\text { Menular (Lembaran Negara } \\
\text { Republik Indonesia Tahun } 1984 \\
\text { Nomor 20, Tambahan Lembaran } \\
\text { Negara Republik Indonesia } \\
\text { Tahun 1984 Nomor 3723); } \\
\text { 2. Undang-Undang Nomor } 20\end{array}$ & $\begin{array}{l}\text { 1. Undang-Undang Nomor } 4 \text { Tahun } \\
1984 \text { tentang Wabah Penyakit } \\
\text { Menular (Lembaran Negara } \\
\text { Republik Indonesia Tahun } 1984 \\
\text { Nomor 20, Tambahan Lembaran } \\
\text { Negara Republik Indonesia Tahun } \\
\text { 1984 Nomor 3723); } \\
\text { 2. Undang-Undang Nomor } 29 \text { Tahun }\end{array}$ \\
\hline
\end{tabular}




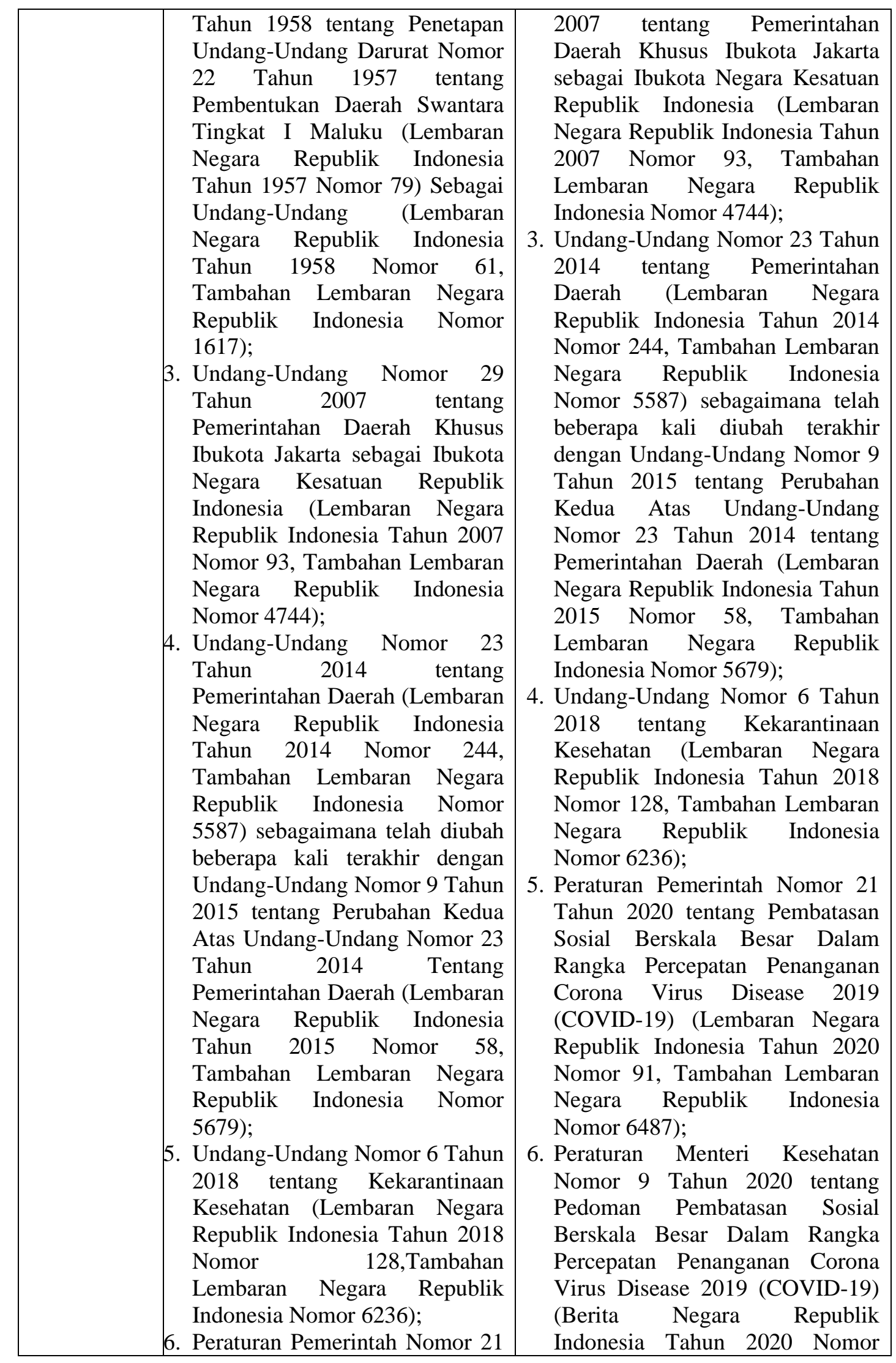




\begin{tabular}{|c|c|c|}
\hline & $\begin{array}{l}\text { Tahun } 2020 \text { tentang Pembatasan } \\
\text { Sosial Berskala Besar Dalam } \\
\text { Rangka Percepatan Penanganan } \\
\text { Corona Virus Disease 2019 } \\
\text { (COVID-19) (Lembaran Negara } \\
\text { Republik Indonesia Tahun 2020 } \\
\text { Nomor 91, Tambahan Lembaran } \\
\text { Negara Republik Indonesia } \\
\text { Nomor 6487); } \\
\text { 7. Peraturan Menteri Kesehatan } \\
\text { Nomor 9 Tahun 2020 tentang } \\
\text { Pedoman Pembatasan Sosial } \\
\text { Berskala Besar Dalam Rangka } \\
\text { Percepatan Penanganan Corona } \\
\text { Virus Disease 2019 (COVID19) } \\
\text { (Berita Negara Republik } \\
\text { Indonesia Tahun 2020 Nomor } \\
\text { 326); }\end{array}$ & 326); \\
\hline Pembatasan & $\begin{array}{l}\text { Pasal } 8 \\
\text { a. penghentian sementara proses } \\
\text { belajar mengajar di sekolah } \\
\text { dan/atau institusi pendidikan } \\
\text { lainnya; } \\
\text { b. pembatasan proses bekerja di } \\
\text { tempat kerja; } \\
\text { c. pembatasan } \\
\text { keagamaan; } \\
\text { d. pembatasan kegiatan di tempat } \\
\text { atau fasilitas umum, dan } \\
\text { e. pembatasankegiatan sosial dan } \\
\text { budaya }\end{array}$ & $\begin{array}{l}\text { Pasal } 5 \text { ayat (4) } \\
\text { a. pelaksanaan pembelajaran di } \\
\text { Sekolah dan/atau institusi } \\
\text { pendidikan lainnya; } \\
\text { b. aktivitas bekerja di tempat kerja; } \\
\text { c. kegiatan keagamaan di rumah } \\
\text { ibadah; } \\
\text { d. kegiatan di tempat atau fasilitas } \\
\text { umum; } \\
\text { e. kegiatan sosial dan budaya; dan } \\
\text { f. pergerakan orang dan barang } \\
\text { menggunakan moda transportasi. }\end{array}$ \\
\hline
\end{tabular}

\section{Sumber: diolah oleh penulis}

Tabel di atas menunjukkan ketidaksinkronan antara judul dan materi muatan dalam Pergub Maluku Nomor 15 Tahun 2020, dan kesamaanpada sistematika materi muatan antara, kesamaan pada dasar hukum yang dijadikan landasan yuridis, dan kesamaan dalam pengaturan pembatasan-pembatasan antara Pergub Maluku Nomor 15 Tahun 2020 dengan Pergub DKI Jakarta Nomor 33 Tahun 2020.

Pengaturan subtansi pembatasan dalam Pasal 8 Pergub Maluku Nomor 15 Tahun 2020 sesuai judulnya, seyogyanya tidak perlu mengatur mengenai penghentian sementara proses belajar mengajar di sekolah dan/atau institusi pendidikan lainnya, pembatasan proses bekerja di tempat kerja, pembatasan kegiatan keagamaan, pembatasan kegiatan di tempat atau fasilitas umum dan pembatasan kegiatan sosial dan budaya, melainkan cukup hanya mengatur pembatasan terhadap pergerakan orang dan moda transportasi, sebagaimana pengaturan pembatasan pada Pasal 5 ayat (4) huruf f Pergub DKI Jakarta Nomor 33 Tahun 2020. 
Kesamaanlain yang sangat nyata adalah dasar hukum pada konsiderans mengingat sebagaimana tercantum pada angka 3, yaitu: 'Undang-Undang Nomor 29 Tahun 2007 tentang Pemerintahan Daerah Khusus Ibukota Jakarta sebagai Ibukota Negara Kesatuan Republik Indonesia (Lembaran Negara Republik Indonesia Tahun 2007 Nomor 93, Tambahan Lembaran Negara Republik Indonesia Nomor 4744)' padahal Pergub yang dimaksud adalah Pergub Maluku, bukan Pergub DKI Jakarta. Walaupun kemudian beredar lagi draft lain yang sudah 'dihapus' angka 3 konsiderans mengingat.

Materi muatan Pergub Maluku Nomor 15 Tahun 2020 yang terkesan 'copypaste' dari Pergub DKI Jakarta Nomor 33 Tahun 2020, jika dikaji berdasarkan prinsip formal pembentukan peraturan perundang-undangan sebagaimana diatur dalam Pasal 5 UU Nomor 12 Tahun 2011, yaitu Prinsip Dapat Dilaksanakan. Di mana setiap pembentukan peraturan perundang-undangan harus memperhitungkan efektifitas peraturan perundang-undangan tersebut di dalam masyarakat, baik secara filosofis, yuridis maupun sosiologis.Kondisi dan keadaan masyarakat dan sertas situasi di Maluku berbeda dengan di Jakarta, sehingga materi muatan Pergub Maluku Nomor 15 Tahun 2020, seyogyanya mengacu pada kondisi riil di Maluku.

Selain daripada itu dari sisi wilayah keberlakuan,Pergub Maluku Nomor 15 Tahun 2020 hanya mengatur keberlakuannya meliputi wilayah Kota Ambon dan tiga kecamatan dari Kabupaten Maluku Tengah yang ada di Pulau Ambon, sedangkan terdapatsembilan kabupaten dan dua kota yang berada dalam Provinsi Maluku, dan tidak diberlakukan pembatasan. Atau dengan kata lain, keberlakuan Pergub Maluku Nomor 15 Tahun 2020 hanya meliputi Pulau Ambon.

Kebutuhan akan pengaturan yang bertujuan untuk mengatasi dan menekan laju penyebaran pandemi Covid-19 di Maluku harus menjadi perhatian pemerintah daerah dalam membentuk produk hukum (peraturan kepala daerah) yang baik. Produk hukum yang dibentuk harus dapat memerhatikan kondisi daerah dan keadaan masyarakat di daerah masing-masing sehingga produk hukum yang dihasilkan mampu memberikan perlindungan kepada masyarakat dan dapat diterapkan dalam masyarakat.

Pemerintah daerah dalam mengambil langkah penanganan untuk mengatasi dan menekan penyebaran pandemi Covid-19 yang bertujuan melindungi masyarakat memiliki kewenangan untuk mengendalikan masyarakat.Pengendalian dapat diejawantahkan dalam bentuk pembentukan produk hukum yang mengendepankan perlindungan dan keselamatan rakyat, dengan tetap berlandaskan pada prinsip peraturan perundang-undangan yang baik.Pengendalian dalam bentuk pembentukan aturan dalam produk hukum daerah diperlukan agar terwujud kesejahteraan dan keselamatan bersama dalam kehidupan bermasyarakat.

Selain itu, perlu juga memerhatikan konsep Good Governance dalam penyelenggaraan pemerintahan negara di daerah, khususnya dalam pembentukan produk hukum daerah di masa pandemi Covid-19. Tetapi, konsep Good Governance yang dimaksud bukanlah dalam pendekatan negara dalam keadaan normal, melainkan konsep Good Governance dalam pendekatan negara dalam 
keadaan tidak normal menghadapi Covid-19. Atau yang oleh M. Guntuh Hamzah $^{20}$ disebut sebagai konsep Good Covid-19 Governance.

\section{Penutup}

Langkah hukum dengan membentuk Peraturan Gubernur, khususnya Pergub Maluku Nomor 15 Tahun 2020 merupakan salah satu langkah cepat dan tepat untukdilakukan sebagai upaya penanggulangan penyebaran Covid-19. Namun Pergub Maluku Nomor 15 Tahun 2020 belum sepenuhnya sesuai dengan prinsip-prinsip formal dan prinsip-prinsip substansial pembentukan peraturan perundang-undangan, karena Pergub Maluku Nomor 15 Tahun 2020 terkesan dibentuksecara terburu-buru dan memiliki banyak kesamaan materi muatan dengan Pergub DKI Jakarta Nomor 33 Tahun 2020.Pemerintah Provinsi Maluku seyogyanya mencabut Pergub Maluku Nomor 15 Tahun 2020 dan membentuk peraturan gubernur yang baru dengan mendasari pada prinsip-prinsip formal dan prinsip-prinsip substansial pembentukan peraturan perundangan menurut UU Nomor 12 Tahun 2011,serta materi muatannyamencerminkan konsep Good Covid-19 Governance. Tujuan penerapan prinsip-prinsip formal dan prinsipprinsip substansial pembentukan peraturan perundang-undangan dan mencerminkan konsep Good Covid-19 Governancedalam pembentukan peraturan gubernur, agar peraturan gubernur yang dihasilkan dapat diberlakukan dan dilaksanakan dalam masyarakat serta menjamin perlindungan masyarakat selama pandemi Covid-19.

\section{DAFTAR BACAAN}

\section{Buku}

Arden, Andrew, 2008, Local Government Constitutional Law and Administrative Law, Thompson Sweet \& Maxwell, London.

Asshiddiqie, Jimly, 2005, Hukum Tata Negara dan Pilar-Pilar Demokrasi, Serpihan Pemikiran Hukum, Media dan HAM, Konstitusi Press, Jakarta.

Burkens, M.C., 1997, Beginselen van de Democratische Rechtsstaat, W.E.J. Tjeenk Willenk, Deventer.

Hadjon, Philipus M., 2007, Perlindungan Hukum Bagi Rakyat di Indonesia, Sebuah Studi tentang Prinsip-Prinsipnya, Penangannya oleh Pengadilan dalam Lingkungan Peradilan Umum dan Pembentukan Peradilan Administrasi, Peradaban, Surabaya.

Manan, Bagir, 2003, Teori dan Politik Konstitusi, FH UII Press, Yogyakarta,

Marzuki, M. Laica, 2006, Berjalan-Jalan di Ranah Hukum, Buku Kesatu, Edisi Revisi Cetakan Kedua, Sekretariat Jenderal dan Kepaniteraan Mahkamah Konstitusi RI, Jakarta.

Marzuki. Peter Mahmud, 2010, Penelitian Hukum, Kencana, Jakarta.

${ }^{20}$ Dalam Webinar dengan "Tema Dinamika Hukum Administrasi dalam Kebijakan Pemerintah Terkait Covid-19”, diselenggarakan oleh KJI pada tanggal 12 Mei 2020. 
Samuel, Geofferey 2007, Epistimology and Method in Law, Kent Law School, UK, Juridishe Bibliotheek University Utrecht.

Soeprapto, Maria Farida Indrati, 2006, Ilmu Perundang-Undangan, Dasar-Dasar dan Pembentukannya, Cetakan Kesebelas, Kanisius, Yogyakarta.

----------, 2007, Ilmu Perundang-undangan, Jenis, Fungsi dan Materi Muatan, Kanisius, Yogyakarta.

Strong, C.F., 1960, Modern Political Constitutions an Introduction to the Comparative Study of their History and Existing Form, Fifth Printed, Sidwick \& Jackson Limited, London.

Syahuri, Taufiqurrohman, 2004, Hukum Konstitusi (Proses dan Prosedur Perubahan UUD 1945 di Indonesia 1945-2002), Ghalia Indonesia, Jakarta.

Utrecht, Ernst, 1983, Pengantar dalam Hukum Indonesia, Ichtiar Baru bekerja sama dengan Sinar Harapan, Jakarta.

\section{Tugas Akhir}

Attamimi, A. Hamid S., 1990, "Peranan Keputusan Presiden Republik Indonesia dalam Penyelenggaraan Pemerintahan Negara (Suatu Studi analisis Mengenai Keputusan Presiden yang Berfungsi Pengaturan dalam Kurun Waktu PELITA I-PELITA IV)", Disertasi, Universitas Indonesia, Jakarta.

Subawa,I Made, 2003, "Implikasi Yuridis Pengalihan Kekuasaan Membentuk Undang-Undang Terhadap Sistem Ketatanegaraan Republik Indonesia Pasca Perubahan Undang-Undang Dasar 1945", Disertasi, PPS Unair, Surabaya.

\section{Peraturan Perundang-Undangan}

Undang-Undang Dasar Negara Republik Indonesia Tahun 1945.

Undang-Undang Nomor 12 Tahun 2011 tentang Pembentukan Peraturan Perundang-undangan (Lembaran Negara Republik Indonesia Tahun 2011 Nomor 82, Tambahan Lembaran Negara Nomor 5234).

Undang-Undang Nomor 30 Tahun 2014 tentang Administrasi Pemerintahan (Lembaran Negara Republik Indonesia Tahun 2014 Nomor 292, Tambahan Lembaran Negara Nomor 5601).

Peraturan Gubernur Provinsi Maluku Nomor 15 Tahun 2020 tentangPembatasan Pergerakan Orang dan Moda Transportasi dalam Penanganan Corona Virus Disease 2019 (Covid-19) di Pulau Ambon (Berita Daerah Provinsi Maluku Tahun2020 Nomor 47).

Peraturan Gubernur Provinsi Daerah Khusus Ibukota Jakarta Nomor 33 Tahun 2020 tentangPelaksanaan Pembatasan Sosial Berskala Besar dalam Penanganan Corona Virus Disease 2019 (Covid-19) di Provinsi Daerah Khusus Ibukota Jakarta (Berita Daerah Provinsi Daerah Khusus Ibukota Jakarta Tahun 2020 Nomor 55003). 